\title{
Ishikawa 細胞培養系におけるエリスロマイシンの
}

\section{緑膿菌バイオフィルム形成抑制能}

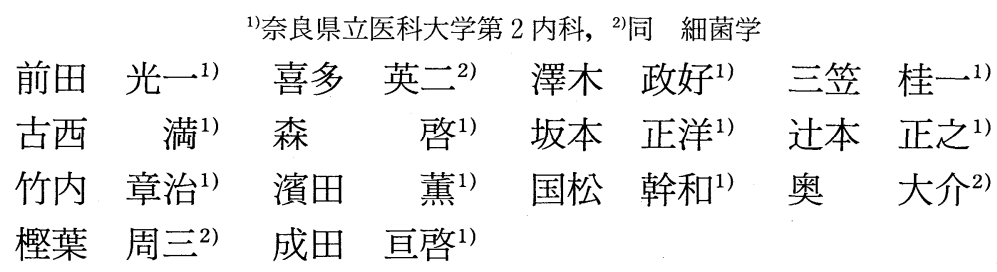

(平成 6 年 4 月 25 日受付)

(平成 6 年 6 月 13 日受理)

Key words: erythromycin, Pseudomonas aeruginosa, biofilm, Ishikawa cell

\begin{abstract}
要旨
ムチン様 glycoprotein を産生する Ishikawa 細胞の培養系を用いて緑膿菌の温度感受性 (Ts) 変異株 によるバイオフィルムモデルを作成し，エリスロマイシン (EM) のバイオフィルム形成抑制効果を検討 した. 本細胞培養系において緑膿菌 Ts 変異株は培養開始10日目で通常約40個/well 前後の microcolony (バイオフィルム) を形成したが, $\mathrm{EM} は 0.2 \mu \mathrm{g} / \mathrm{ml}$ の濃度から細胞への菌付着およびバイオフィルム形 成を抑制し得た。この系の培養上清中の glycoprotein 量は $1 \mu \mathrm{g} / \mathrm{ml}$ 以上の EM 濃度で, また elastase, exoenzyme A 量は $2 \mu \mathrm{g} / \mathrm{ml}$ 以上の EM 濃度で抑制された. 以上から細胞培養系での緑膿菌によるバイオ フィルム形成抑制効果が EM に存在することが示唆された。また菌体外酵素産生を抑制する EM 濃度以 下でバイオフィルム形成抑制および Ishikawa 細胞からの glycoprotein 産生抑制がみられたことから, EM のバイオフィルム抑制効果は細胞側因子への作用の関与がより大きいものと考えられた.
\end{abstract}

\section{はじめに}

びまん性汎細気管支炎をはじめとする慢性下気 道感染症に対するエリスロマイシン (EM) による 長期化学療法の有効性はすでに確立されたが，そ の作用機序は細菌と宿主細胞の両方に対するもの と考えられる ${ }^{12)}$. その機序の一つとして, 難治性 慢性下気道感染症の病態で重要とされる緑膿菌バ イオフィルム ${ }^{3} に$ 対する $\mathrm{EM}$ の作用を明らかにす る目的で, ムチン様 glycoprotein を産生する Ishikawa 細胞の培養系を用いて緑膿菌のバイオフィ ルムモデルを作成し,この系における $\mathrm{EM}$ のバイ オフィルム形成抑制能の検討を行った.

別刷請求先：（元634）橿原市四条町840 奈良県立医科大学第 2 内科 前田 光一

\section{材料と方法}

細菌：Pseudomonas aeruginosa N-42（臨床分 離株）から Hooke らの方法 ${ }^{4}$ に準じて誘導した温 度感受性変異株 Ts25を用いた。すなわち緑膿菌に $\mathrm{N}$-nitrosoguanidine を作用させ温度感受性変異 株を誘導し, ceftazigime と imipenem/cilastatin を用いて $37^{\circ} \mathrm{C}$ 増殖菌を殺菌した後, replica 法にて $37^{\circ} \mathrm{C}$ で非発育の菌のみを選択した。本変異株は

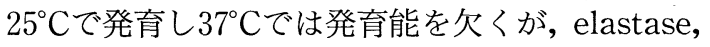
exoenzyme $\mathrm{A}$ などの菌体外酵素を $37^{\circ} \mathrm{C}$ で非増殖 下に産生する能力は維持しており, その産生量は 親株の約 $45 \%$ であった。

培養細胞：ヒト子宮内膜腺癌由来の細胞株で, 気道粘液に性状が類似したムチン様 glyco- 
protein を産生する Ishikawa 細胞占を用いた。本 細胞を 24 穴平底プレートに $10^{4} / \mathrm{ml}$ の濃度で $5 \%$ fetal bovine serum を含む $1 \mathrm{ml} の$ minimal essential medium (MEM) と共に入れ, confluent monolayer が形成されるまで $5 \% \mathrm{CO}_{2}$ 内で $37^{\circ} \mathrm{C} て ゙$ 培養した。气の後 monolayer $50 \mu \mathrm{g} / \mathrm{ml}$ の mitomycin $\mathrm{C}$ で $37^{\circ} \mathrm{C}$ で30分間処理し洗浄後, 同様 の培養液で24時間培養し実験に用いた。

バイオフィルム形成：mitomycin Cで処理し た Ishikawa 細胞を $10 \%$ 七ト新鮮血漿と $10^{7} \mathrm{col}$. ony forming units (CFU) 量のTs25株を含む MEM で $37^{\circ} \mathrm{C}, 5 \% \mathrm{CO}_{2}$ 内で24時間培養後, Hank' $\mathrm{s}$ balanced salt solusion で洗浄し非付着菌体を除 去した。そして0.2 $10 \mu \mathrm{g} / \mathrm{ml}$ の濃度の EM を添 加，あるいは非添加下に $10 \%$ 上卜血漿含有 $\mathrm{MEM}$ でさらに培養し, 位相差顕微鏡で microcolony の 形成状態を観察した。 mitomycin C 処理による Ishikawa 細胞の glycoprotein 産生量は非処理細 胞の約 $60 \%$ であった。なお microcolony 数の算定 は弱拡大による位相差顕微鏡下での測定と写真撮 影による測定を行い, 二法による平均值を求めた。

生菌数の算定：microcolony 形成後, monolayer $0.05 \%$ Triton X 溶液で溶解し, 音
波処理を施し，種々の希釈濃度で tryptic soy agar plateして $25^{\circ} \mathrm{C}$ で 48 時間後 $\mathrm{CFU}$ 数を計測 した.

培養上清中 glycoprotein, elastase, exoenzyme A の定量：glycoprotein の分離は培養上清に $5 \mathrm{M}$ $\mathrm{NaCl}$ を50：1の割合に加え，20,000G で 1 時間 遠心後，遠心上清に $95 \%$ エタノールを加え，ゲラ チン様の沈澱物を5,000G，40分間の遠心で回収し た。これを $95 \%$ エタノルで十分に洗浄したもの を Ishikawa 細胞由来 glycoprotein として用い た。また緑膿菌 elastase は Nagase Biochemical 社製, exoenzyme A は List Biochemical 社製の 標品を使用した。glycoprotein と elastase に対す る抗体は, Freund complete adjuvant (Difco 社) を用いて過免疫にした家鬼の血清から硫安沈澱法 にて免疫グロブリン分画を得, DEAEイオン交換 クロマトグラフィーにより得た IgG 分画を抗体 として用いた。 exoenzyme Aに対する抗体は List Biochemical 社製の抗 exoenzyme A 抗体を 用いた。これらの精製標品とそれぞれの抗体を用 いてロケット免疫電気泳動法奋にてスタンダード 曲線を作成し定量した。なお exoenzyme Aの定 量には泳動前に培養上清をCentricon（ナカライ

Fig. 1a: Normal appearance of Ishikawa cells, b: Initial formation of biofilms (microcolonies), c: Two biofilm colonies $(\times 600)$

a

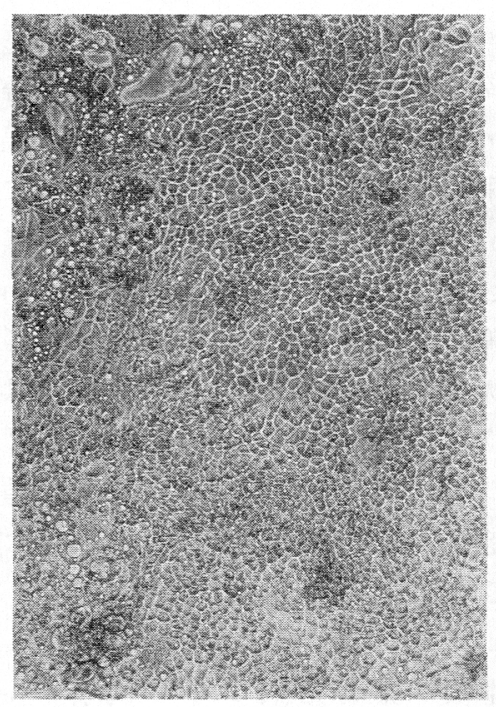

$\mathrm{b}$

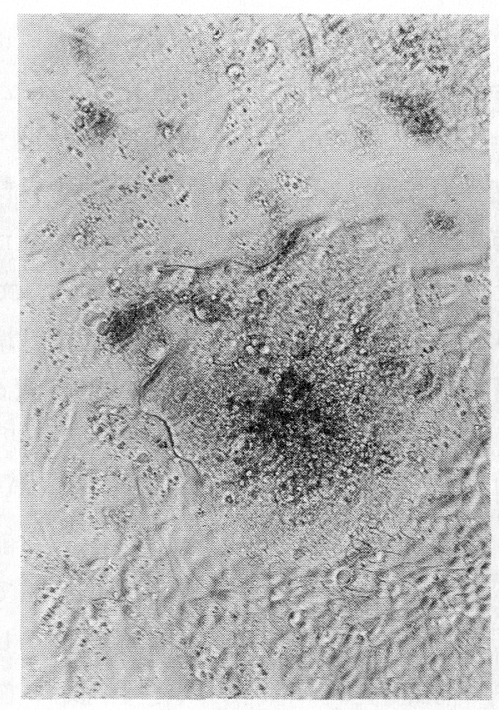

C

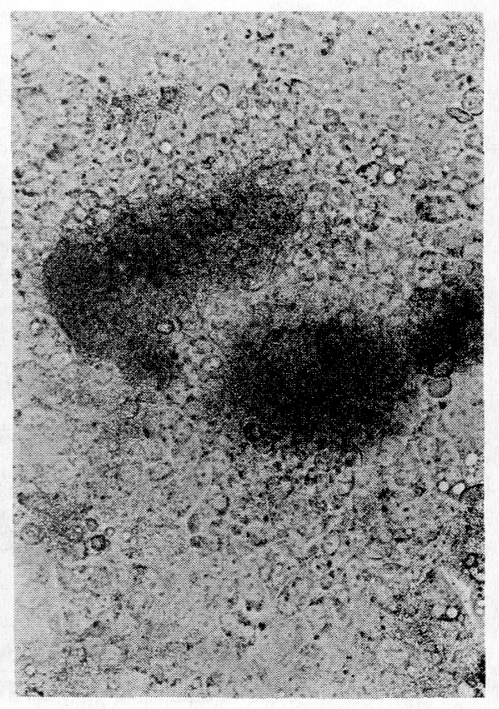

感染症学雑誌 第68巻 第10号 
テスク社)で100倍濃縮し泳動に用いた。また糖定 量はアンスロン法, 蛋白定量は Bio-Rad 社の dyebinding assay kitにより行った。

\section{成 績}

\section{1. バイオフィルムの形成}

Ishikawa 細胞培養系において緑膿菌 Ts 変異 株は培養開始10日目で位相差顕微鏡下で十分に観 察し得る microcolony (バイオフィルム)を通常約 40個/well 程度形成した (Fig. $1 \mathrm{a} \sim \mathrm{c})$.

2. EM によるバイオフィルム形成抑制

この系において $\mathrm{EM} は 0.2 \sim 0.5 \mu \mathrm{g} / \mathrm{ml}$ の濃度 からバイオフィルム形成を抑制し, $2 \sim 5 \mu \mathrm{g} / \mathrm{ml}$ で 完全に抑制した (Table 1). バイオフィルム数の 減少に伴い well 中の緑膿菌数の減少が確認され た (Fig. 2).

Table 1 Effect of erythromycin on biofilm formation in culture of Ishikawa cells

\begin{tabular}{cc}
\hline $\begin{array}{c}\text { EM } \\
\text { concentrations } \\
(\mu \mathrm{g} / \mathrm{ml})\end{array}$ & $\begin{array}{c}\text { No. of microcolonies } \\
\text { (mean } \pm \mathrm{SD} / \text { well })\end{array}$ \\
\hline 0 & $43 \pm 15$ \\
0.2 & $18 \pm 6$ \\
0.5 & $12 \pm 4$ \\
1 & $3 \pm 2$ \\
2 & $<2$ \\
5 & 0 \\
10 & $5 \pm 2$ \\
\hline
\end{tabular}

Fig. 2 The number of $P$. aeruginosa Ts25 colonizing the monolayers of Ishikawa cells in the presence of erythromycin.

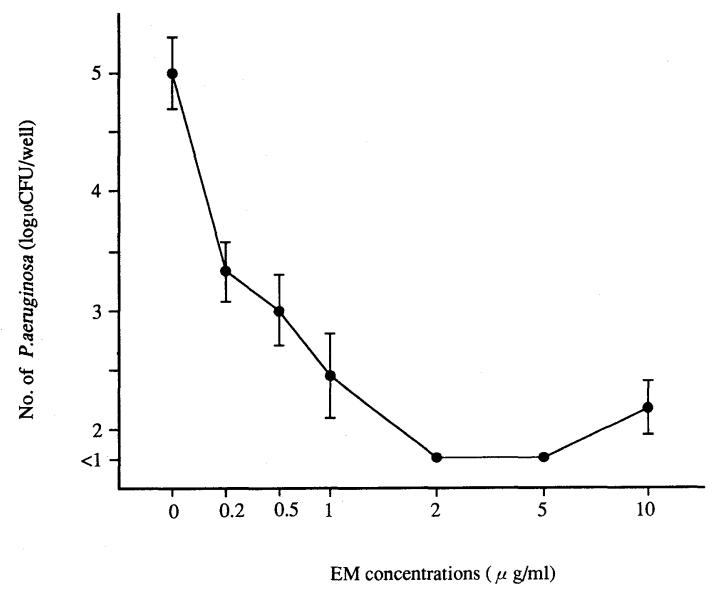

3. EM による glycoprotein, 菌体外酵素産生抑 制

培養上清中の Ishikawa 細胞から産生される glycoprotein 量は $1 \mu \mathrm{g} / \mathrm{ml}$ 以上の $\mathrm{EM}$ 濃度で抑制 され (Fig. 3), 緑膿菌の菌体外酵素である elastase, exoenzyme A は $2 \mu \mathrm{g} / \mathrm{ml}$ 以上の $\mathrm{EM}$ 濃度で 抑制された (Fig. 4，5).EM のバイオフィルム形 成抑制効果, Ishikawa 細胞からの glycoprotein 産生抑制効果, および緑膿菌の菌体外酵素産生抑 制効果はいずれも $5 \mu \mathrm{g} / \mathrm{ml}$ で最大となり，10 $\mu \mathrm{g} /$ $\mathrm{ml}$ ではこれらの EM の抑制効果は若干低下する

Fig. 3 Effect of erythromycin on glycoprotein production by Ishikawa cells cultured with $P$. aeruginosa Ts25.

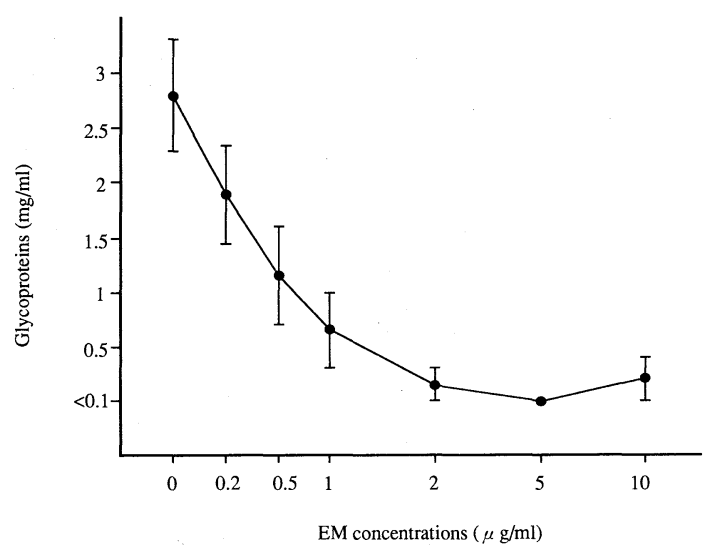

Fig. 4 Effect of erythromycin on elastase production by $P$. aeruginosa Ts25 in culture with Ishikawa cells.

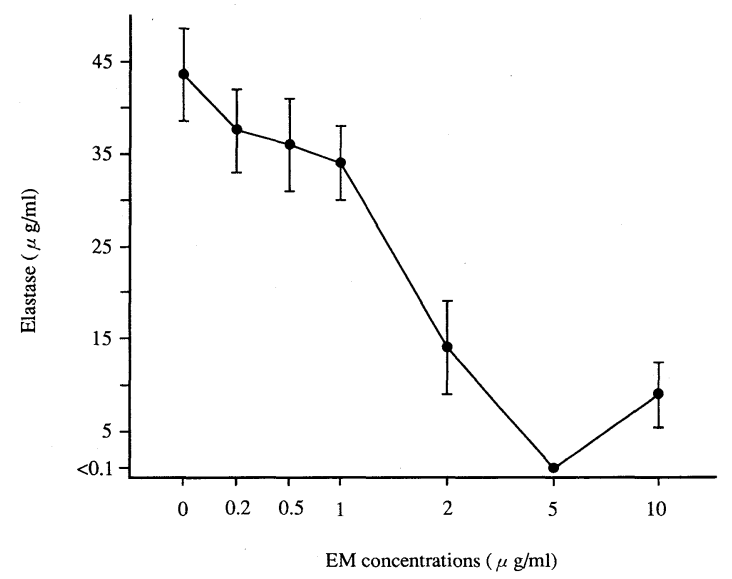

平成 6 年 10 月 20 日 
Fig. 5 Effect of erythromycin on exoenzyme A production by $P$. aeruginonal Ts 25 in culture with Ishikawa cells.

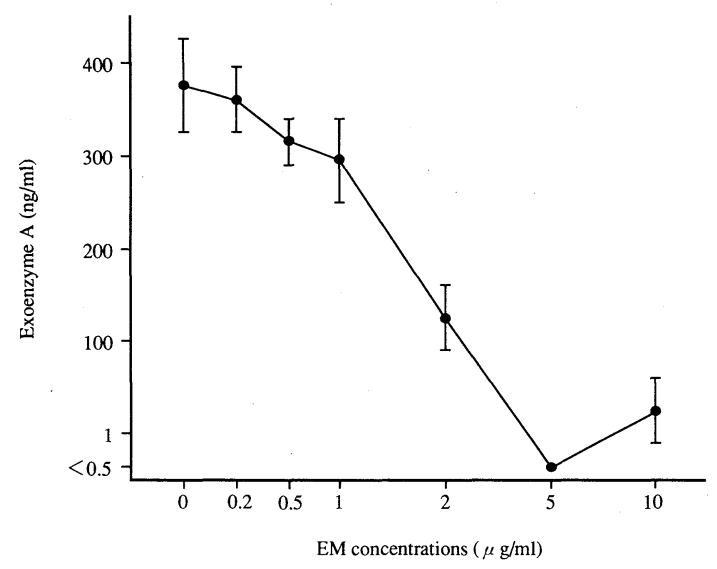

傾向にあった.

\section{考 察}

緑膿菌は欧米での cystic fibrosis や本邦でのび まん性沉細気管支炎をはじめとする慢性下気道感 染症において持続的慢性感染を惹起し難治化す $ろ^{778)}$. その機序の一つとして緑膿菌の気道粘膜へ の付着と，それに続いて菌体表層の glycocalyx を介して互いに凝集し形成されるバイオフィルム が近年注目されている319). glycocalyx を介する組 織への付着は緑膿菌の pili を介した特異的付着に 比べ非常に強固であるとされ(10)，さらにこの glycocalyx による粘着・凝集に加え，血漿成分や 粘液などが付着しバイオフィルムは一層強固にな ると考えられる ${ }^{3) 9}$.こうして形成されたバイオ フィルム内の細菌は各種抗菌薬や宿主の食細胞に よる攻撃を受けることなく，長期的に気道表面に 定着し気道の排出機構を傷害して慢性的な症状が 持続するようになるとされている ${ }^{11)}$.このように 慢性下気道感染症の病態において気道粘膜表面で の緑膿菌のバイオフィルム形成は本症の難治化の 一因として極めて重要であると考えられる。

緑膿菌性慢性下気道感染症に対する $\mathrm{EM}$ やク ラリスロマイシン (CAM) などのマクロライド系 抗菌薬の有効性が明らかとなっているが212), その 作用機序の検討で最近, EM と CAM の緑膿菌の 付着に対する抑制作用が報告されている(13) 16). In vitro での緑膿菌バイオフィルムの形成は菌体表 層の glycocalyx による菌体同士の接着が大きな 要因 ${ }^{9}$ であると考えられるが，気道粘膜表面にお いてはバイオフィルムは緑膿菌と宿主細胞との相 互作用によって形成されるものと考えられる。そ こで今回， EM の緑膿菌バイオフィルム形成に対 する作用を細菌側および宿主細胞側の両面から検 討する目的で Ishikawa 細胞の培養系を用いた緑 膿菌バイオフィルムモデルを作成した. Ishikawa 細胞は七卜子宮内膜腺癌由来の細胞株で5), 気道 で産生される粘液に物理化学的性状が非常に類似 した glycoprotein を産生する性質を持ち, 上皮細 胞からの粘液産生に対する種々の薬剤の薬理作用 を検討するためのモデルとして用いられてい

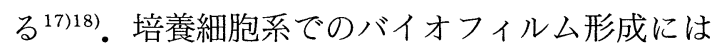
7 日間以上の培養を必要とするため, 本研究では Ishikawa 細胞を mitomycin C で処理し増殖を停


を保持する緑膿菌温度変異株(Ts25) ${ }^{4)}$ を用い, EM のバイオフィルム抑制効果を検討した.

この培養細胞系における検討の結果, $0.2 \mu \mathrm{g} / \mathrm{ml}$ の $\mathrm{EM}$ 濃度から Ishikawa 細胞の monolayer 上 に形成される microcolony 数とその中の生菌数 の減少を認め, EM には比較的低い濃度から緑膿 菌バイオフィルムの形成抑制効果があることが観 察された。また EM は緑膿菌の菌体外酵素産生抑 制作用がある ${ }^{19)}$ 一方，ヒ卜気道上皮培養細胞から の glycoprotein 産生を抑制することが示されて いるが ${ }^{18)}$, 今回の検討でこの系での培養上清中の Ishikawa 細胞から産生される glycoprotein 量と 緑膿菌からの菌体外酵素産生量を測定したとこ ろ, 両者が最大に抑制される $\mathrm{EM}$ 濃度 $(5 \mu \mathrm{g} / \mathrm{ml})$ でバイオフィルム形成抑制効果も最大であった. このことから EM のバイオフィルム形成抑制は Ishikawa 細胞と細菌の双方に対する作用による ものと考えられた.しかし Ishikawa 細胞の glycoprotein と緑膿菌の菌体外酵素の産生抑制 効果を発現する $\mathrm{EM} の$ 最小量を比較すると, glycoprotein 産生に対する抑制効果は菌体外酵 素産生抑制効果を発現する EM 濃度以下 $(1 \mu \mathrm{g} /$ $\mathrm{ml})$ で認められ，この濃度よりさらに低い $0.2 \mu \mathrm{g} /$ 
$\mathrm{ml}$ でもバイオフィルム形成抑制がみられた.この ことからヒト上皮細胞培養系における緑膿菌によ るバイオフィルム形成に対する EM の抑制効果 は宿主細胞により強く依存している可能性が示唆 された。

今回のこれらの結果は緑膿菌バイオフィルムの 病態および治療を考える上で興味深く, 今後さら に細菌バイオフィルムについて細菌と宿主の両面 から検討する必要があると考えられた。

本論文の要旨は第41回日本化学療法学会西日本支部総会 (1993年12月, 神戸) において報告した。

Ishikawa 細胞を御供与いただいた筑波大学臨床医学系 産婦人科, 西田正人先生に深謝いたします。

なお本研究の一部は厚生省特定疾患びまん性肺疾患調査 研究班補助金によった.

\section{文献}

1）澤木政好，三笠桂一：慢性下気道感染症における エリスロマイシン長期投与法. 化学療法の領域, 6: 257-265, 1990.

2）三笠桂一，澤木政好, 古西 満, 前田光一, 竹内 章治, 濱田 薰, 国松幹和, 増谷喬之, 佐野麗子, 喜多英二, 樫葉周三, 成田亘啓 : 難治性緑膿菌性 慢性下気道感染症に対する erythromycin (EM) 長期治療の検討一Quality of life からの観点も含 めて一. Chemotherapy, 40:647-653, 1992.

3）小林宏行, 大垣憲隆: 慢性気道感染症一biofim desease としてのアプローチー。呼吸, 11: 1266 $-1271,1992$.

4) Hooke, A.M., Oeschger, M.P., Zeligs, B.J. \& Bellanti, J.A.: Ideal target organism for quantitative bactericidal assays. Infect. Immun., 20: 406-411, 1978.

5）西田正人, 笠原国武, 金子 實, 岩崎寛和, 林 雄：エストロゲン，プロゲステロンレセプターを 持つ七ト分化型子宮内膜腺癌細胞株（Ishikawa 株）の樹立. 日産婦誌，37：1103-1111, 1985.

6) Ganrot, P.O.: Crossed immunoelectrophoresis. Scand. J. Clin. Lab. Invest., Suppl. , $124: 39$ $-40,1972$.

7) Pier, G.B.: Pulmonary disease associated with Pseudomonas aeruginosa in cystic fibrosis: Current status of the host-bacterium infection. J. Infect. Dis., 151: 575-580, 1985.

8）古西 満, 澤木政好, 三笠桂一, 竹内章治, 柳生 善彦, 濱田 薰, 国松幹和, 成田亘啓, 佐野麗子, 増谷喬之：慢性下気道感染症における細菌感染症 の検討一急性感染症と慢性感染症の観点から一. 感染症誌, 65 : 1593-1599, 1991.

9) Costeton, J.W., Cheng, K.J., Geesey, G.G., Ladd,
T.I., Nickel, J.C., Dasgupta, M. \& Marrie, T.J. : Bacterial biofilms in nature and disease. Ann. Rev. Microbiol., 41 : 435-464, 1987.

10) Bryers, J.D. \& Characklis, W.G.: Early fouling biofilm formation in a turbulent flow system: Overall kinetics. Water Res., 15: 483 $-491,1981$.

11) Anwar, H. \& Costerton, J.W. : Enhanced activity of combination of tobramycin and piperacillin for eradication of sessile biofilm cells of Pseudomonas aeruginosa. Antimicrob. Agents Chemother., $34:$ 1666-1671, 1990.

12）三笠桂一，澤木政好，喜多英二，古西 満，前田 光一, 濱田 薰, 竹内章治, 増谷喬之, 佐野麗子, 国松幹和，樫葉周三，成田亘啓：慢性下気道感染 症に対する Erythromycin (EM) 長期化学療法の 検討一第 4 報：EM無効例に対するClarithromycin 有効性について一. 感染症誌，66:1097 $-1104,1992$.

13）山崎 透：緑膿菌の気道粘膜付着能とそれに及ぼ す抗菌剤の影響. 感染症誌, 64: 575-583, 1992.

14）武田博明，大垣憲隆，菊池直美，小林宏行，明石 敏：びまん性汎細気管支炎に対するマクロライド 作用の検討一緑膿菌 biofilm に対するクラリスロ マイシンの影響一. 感染症誌, 66: 1454-1461, 1992.

15）中塩哲士，須佐千尋，邱世林，木島あゆみ，岩 崎博子, 下村晴信, 金光敬二, 堀 誠二, 水島 裕, 嶋田甚五郎: Clarithromycin $の$ in vitro 抗菌力 と細菌の粘着抑制作用に関する研究. J. J. Antibiol, 46: 428-436, 1993.

16）三笠桂一, 喜多英二, 澤木政好, 古西 満, 前田 光一, 濱田 薰, 竹内章治, 坂本正洋, 国松幹和, 樫葉周三, 成田亘啓 : 細菌の細胞障害毒素産生と 接着因子に及ぽす erythromycin の影響. 感染症 誌, 67: 648-653, 1993.

17) Amin, D.N., Goswami, S., Klein, T., Maayani, S. \& Marom, Z.: Functional antagonism between hormone receptor systems: Modulation of glycoprotein secretion in secretory epithelial cells. Am. J. Respir. Cell Mol. Biol., 4: 135-139, 1991.

18) Goswami, S.K., Shmuel, K. \& Marom, Z.: Erythromycin inhibits respiratory glycoconjugate secretion from human airway in vitro. Am. Rev. Respir. Dis., 141: 72-78, 1990.

19) Kita, E., Sawaki, M., Oku, D., Hamuro, A., Mikasa, K., Emoto, M., Takeuchi, S., Narita, N. \& Kashiba, S.: Suppression of virulence factors of Pseudomonas aeruginosa by erythromycin. J. Antimicrob. Chemother., 27: 273 $-284,1991$. 
Suppression of the Pseudomonas aeruginosa-Induced Biofilm Formation on Human Epithelial Cells by Erythromycin

Koichi MAEDA ${ }^{1)}$, Eiji KITA ${ }^{2)}$, Masayoshi SAWAKI ${ }^{1}$, Keiichi MIKASA ${ }^{1)}$, Mitsuru KONISHI ${ }^{1}$, Kei MORI ${ }^{1)}$, Masahiro SAKAMOTO ${ }^{1)}$, Masayuki TSUJIMOTO ${ }^{1)}$, Shoji TAKEUCHI ${ }^{1)}$, Kaoru HAMADA ${ }^{1)}$, Mikikazu KUNIMATSU ${ }^{1)}$, Daisuke OKU ${ }^{2)}$, Shuzo KASHIBA ${ }^{2)}$ \& Nobuhiro NARITA ${ }^{1)}$

${ }^{1)}$ The Second Department of Internal Medicine, ${ }^{2)}$ Department of Bacteriology, Nara Medical University

In the present study, were examined the inhibitory effect of erythromycin on the biofilm formation by a temperature-sensitive mutant (Ts25) of Pseudomonas aeruginosa N-42 on the surface of Ishikawa cells which can produce a mucin-like glycoprotein physicochemically similar to mucoproteins produced in the human airway.

Usually, 38-45 microcolonies (biofilms) were formed after 10 days of incubation in cultures of Ishikawa cells and $P$. aeruginosa Ts25. Erythromcin suppressed the adhension to Ishikawsa cells of $P$. aeruginosa and its subsequent biofilm formation at doses as low as $0.2 \mu \mathrm{g} / \mathrm{ml}$. Erythromycin also exhibited the suppressive effect on the production of glycoproteins by Ishikawa cells at doses higher than $1 \mu \mathrm{g} / \mathrm{ml}$ and the production of elastase and exoenxyme A from $P$. aeruginos a doses higher than $2 \mu \mathrm{g} / \mathrm{ml}$.

These results suggest that erythromycin can inhibit the biofilm formation in culture of human epithelial cells and $P$. aeruginosa and the in-vivo bacterial biofilm formation may be attributed to host cell-derived factors rather than bacterial products. 